\title{
Changes and inequality in Latin American families
}

Irma Arriagada

Social Development Division, ECLAC

iarriagada@eclac.cl
The family -a key institution in people's lives- tends to be examined as though it were static and immutable over time.

This paper seeks to shed some light on the changes which have affected the family in a broader socio-economic and cultural context, highlighting the processes of modernization and modernity and their effects on families, by making a diagnostic study of families in the region which describes the changes that have taken place, the diversity of families in different socioeconomic strata, and their heterogeneous structures, according to their type and the stage reached in the family life cycle. In addition to showing the increasing economic inequality between families, the study also highlights the various types of cultural changes to which the family has been subjected, including demographic changes, the growing number of households headed by women, and the increasing participation of women both in the labour market and in the social and political domains. 


\section{I}

\section{Introduction}

People place great trust in the family, seeing it as the institution of first resort in times of hardship or crisis. The family has been described as "a field of action where the most basic dimensions of human security are defined: the processes of personal physical reproduction and social integration" (UNDP, 1998, p. 192).

Most analyses and policy proposals accord a central role to the family in explaining individual behaviour and when designing policies to tackle a variety of social problems. At the same time, it is frequently held that changes in traditional family structures tend to be associated with social disintegration.

During the 1960s and 1970s, the prevailing development model stressed the need to strengthen the family, visualized implicitly or explicitly in terms of a single desirable model, and it was studied rather as an intermediary between individuals and public policies. The gap between this single standard family model and reality, compounded by the outdated approaches taken to the family in public policies, hindered proper analysis of the effects of such policies on families and their members. Thus, there is a striking mismatch between the importance given to the family in government discourse and the public utterances of civil and religious institutions and individuals, ${ }^{1}$ on the one hand, and the scant attention paid to it in social diagnoses and public policies and the time it takes for legal aspects of the family to adapt to new social situations, on the other.

As a complex and dynamic institution, the family faces an additional paradox. On the one hand, it provides shelter and support in the face of changing

The author is grateful for comments made by Virginia Guzmán, Martín Hopenhayn, Miriam Krawczyk and Jorge Rodríguez, it being understood, of course, that any remaining errors or omissions are the author's responsibility. The household surveys were processed by Ernesto Espíndola.

${ }^{1}$ For example, the 2000 World Values Survey found that $96 \%$ of respondents in Chile considered the family the most important aspect of their lives (Corporación Latinobarómetro, 2000), while an opinion survey conducted in Mexico in 1994 found that $85 \%$ of those interviewed considered the family "very important" (quoted in Salles and Tuirán, 1996). conditions that generate insecurity in the fields of work (e.g., unemployment, low wages); health (drug addiction, sickness and death); education (exclusion); and violence (crime). At the same time, the changes that families have undergone over time, compounded by the effects of external tensions and relations inside families, can generate major sources of internal insecurity such as changes in marital status (separation, divorce), migration and domestic violence. From this standpoint, the family is highly vulnerable to crises, yet it is also the institution most often turned to in dealing with them.

This article adopts a gender-based perspective: while the family is analysed as a field for the exercise of personal rights, individual family members interact with unequal and asymmetric power in it. It is interesting to note the new combinations of gender inequality, life cycles and income that are emerging, together with the new paradoxes that families display in the context of modernity and modernization tempered by exclusion which is typical of Latin American societies. This paper aims to shed light on the changes that have affected the family in a wider socioeconomic and cultural context, with special attention to the relations that exist between modernization and modernity and the changes taking place in the family. In order to do so, it makes a diagnostic study of Latin American families that describes the changes that have occurred and the diversity that exists among families in different social strata.

It is worth emphasizing that it is very difficult to carry out diagnostic studies and formulate policies on the family, because the very concept of the family is ideologically biased. This subject cannot be approached dispassionately, because unlike other social and economic subjects, all individuals have empirical knowledge of it, since they were born into and/or have formed a family themselves. The family is perceived as an immutable institution that performs functions which are essential to people's well being: functions that have remained constant through time. In many cases, knowledge, feelings and individual perceptions in relation to the family become stereotyped into uniform models and ideals that obscure the diversity of situations and experiences that exist in reality. 
Another problem in analysing the situation of families is the non-historical approach that is normally used. Among many other aspects, there are two basic time dimensions that need to be considered: the historical evolution of family structures associated with modernization and their individual development paths in different social classes; and the evolution of a given family through time as it passes through the family life cycle, taking account of the fluidity of family structures and the changes taking place in them (ranging, for example, from consensual unions, through marriage and divorce, to "blended families"). ${ }^{2}$ These dimensions are difficult to capture through traditional statistical data, which usually focus on different families at a single moment of time and do not recognize the category of blended family.

The data sources used for this diagnosis are the 1990 and 1999 household surveys. As these consider only two points in time, they cannot be used to analyse family evolution. Accordingly, this paper makes only a cautious analysis of aspects derived from the data used, supported by other sources including studies that illustrate aspects that have not been investigated in surveys of internal family organization, together with references of a more historical nature.

\section{II}

\section{Modernity, modernization and the family}

\section{Family studies}

The classic paradigms of sociological studies have stressed the family's central role in the functioning of society -either invoking a structural-functionalist tradition that relates family matters to the stability of institutions and ultimately society itself, or from the Marxist perspective that perceives close links between changes in the family and developments in other social institutions such as private property, social class, industrial society and the State.

Classical sociology theory tried to identify a synchronic relationship between the organization of society and family structure, within the moderntraditional, urban-rural, secular-religious continuums developed by various sociologists interested in modernization processes (DANE, 1998). The functionalist studies of the family that began to appear in the 1950s focus on the nuclear family. Their predominant thesis postulates a progressive nuclearization of the family as societies modernize. The nuclear family was perceived as being organized on the basis of a clear differentiation between the sexes: men were seen as the economic providers through labour market activity, while women were responsible for matters concerning reproduction and the provision of domestic care for their menfolk, children and elderly

\footnotetext{
${ }^{2}$ In this article, the term "blended" family includes those resulting from divorce, marriage annulment or breakup of consensual unions and the formation of new relationships.
}

family members (Aguirre and Fassler, 1994). These roles were perceived as complementary. More recent studies from different social, cultural, psychological and gender perspectives revealed a much more complex reality, however, both historically and in terms of the modern family.

Studies in the Marxist tradition focused on the new organization of industrial production and its effects both on production and on family reproduction. The move from craft-based work in the home that generated family incomes, to commercial production in factories paying individual wages, gave rise to a large-scale debate in which the key analytical issue was the ways in which monogamous families related functionally to private property. In these studies, special attention was devoted to historical analysis of how families were constructed with different productive (male) and reproductive (female) roles, although this approach placed greater emphasis on analysing relations between the family and the social system than on internal relations within the family. Part of this theoretical tradition has been updated in feminist studies that revive the debate on productive and reproductive work and its interrelations with the economics (and sociology) of care-giving. ${ }^{3}$

The link between family change and modernization processes was thus recognized early in sociological analysis, in terms of the development of the nuclear

\footnotetext{
${ }^{3}$ The economics of care-giving involves the provision of goods and services to take care of other people, particularly family members, usually by women.
} 
family and individual income. Nonetheless, the associated concept of the patriarchal family was not addressed in depth in the leading theories on the family in vogue at the time, especially those in the North American structural-functionalist tradition.

More recently, and from the very start of gender studies, a more critical view has been taken of the asymmetries that exist between family members in terms of power, resources and negotiating capacity. In this respect, the greatest power is generally associated with whoever generates the family's monetary income, or the person that cultural norms expect to do so (usually the male head of household). Attention has also been drawn to the way the distribution of resources, power and time affects women's differential participation in the labour market, politics and public life generally, and the inequality between family members with different degrees of power on account of their sex and age has been highlighted, thereby demonstrating the persistence of gender asymmetries.

The sex and age of family members, and the stages of the family life cycle, are also important dimensions of household structure that need to be considered, both as regards decision-making and access to and use of the resources of the household. ${ }^{4}$ Consideration of the dominance relation that exists between men and women -not only within the family but also at work, in bureaucratic matters and in the media- gives the lie to the fantasy image of the "Eternal Feminine", bringing the fact of male dominance as a historical constant into sharper relief (Bourdieu, 2000, pp. 126-127). The idea of the family as a sphere of private decisions has also been questioned, since decision-making is heavily influenced by the laws and by the economic, social, and population policies being applied. The family is highly susceptible to outside intervention.

Similarly, new studies on masculinity draw attention to the disservice done to women and men alike by a model that promotes rigidly defined roles. One of the most powerful guiding forces in men's lives is that work is what gives them autonomy, makes them providers and turns them into household heads and authorities in the family. ${ }^{5}$

\footnotetext{
${ }^{4}$ Different levels of ability or disability (physical or psychological impediments) also place family members in vulnerable situations. The American Psychological Association Presidential Task Force on Violence and the Family has documented the difficulty of measuring situations involving the abuse of elderly and disabled people in the family. www.apa.org/pi/aging.

${ }^{5}$ Paternal authority in the family was one of the controversial issues addressed at the International Conference on Population and
}

The twentieth century patriarchal family makes a clear distinction between the public and private domains, with a sharp division of labour between men and women. The man is responsible for establishing a family, based on very clear structural relations of authority and affection towards his wife and children, which are legitimized in the outside world and enable him to provide for, protect and guide his family. Women, on the other hand, are expected to complement and collaborate with the husband/father (Olavarría and Parrini, eds., 2000). In most Latin American countries the law reflects this traditional family model, which displays a strong resistance to change. ${ }^{6}$

In Latin America, gender systems in urban mestizo societies were profoundly marked by the Spanish colonial legacy, which attached great importance to the separation between the public and the domestic domains, control of female sexuality, the concept of family honour, recognition by other men, and fatherhood as a means of asserting one's masculinity. Historically, class and ethnic differences intensified control over women's sexuality, allowing men the possibility of having relationships with women from different social groups according to different rationales and moral codes. On the other hand, the fragile nature of public institutions in those societies led to the domestic/public contrast being perceived in territorial terms: in the home or on the street. While the home is an ordered space where kinship relations and personal networks unfold, the street is an ambiguous space where personal desires override the common interest (Fuller, 1997). This patriarchal model of the family is currently being questioned both in public and in private, and there is a striking variety in people's representations, discourses and practices.

Thus, modern family studies see the interaction between gender, social classes and ethnic groups as central pillars of inequality which define very different conditions of life and structures of opportunities, while looking closely at the interrelations between individual time-frames, family cycles and social processes.

Development in Cairo in 1994 and the Fourth World Conference on Women: Action for Equality, Development and Peace, held in Beijing in 1995.

${ }^{6}$ Nonetheless, there have been a number of positive changes, such as the Responsible Parenthood Act recently passed in Costa Rica and the legislation against domestic violence passed in most of the countries of the region. 


\section{Modernity and modernization in Latin America - or modernity with exclusion}

A widely debated and recurrent theme in sociology, in the industrialized and Latin American countries alike, concerns modernization and the social and economic processes that accompany it. The consideration of modernity, in contrast, mainly focuses on normative aspects, cultural dimensions and acceptance of the diversity of identities in pluralistic societies. In general these two processes have not evolved in the same direction. The relation between the processes of subjectivization (characteristic of modernity) and modernization has proven to be unpredictable, asynchronous and at times contradictory (UNDP, 1998).

The distinguishing aspects of modernity include the changes which have occurred within the family and the dimensions most closely related to social identity processes that tend to generate increasing autonomy -especially the changing social roles of women, as discussed below.

The distinction between the processes of modernization and modernity is analytical, for the two concepts are closely interrelated. Some dimensions are shared-for example, the progressive secularization of collective action, which began with the separation of powers between the State and the Church, but later, in the case of the family, involves recognition of the right to divorce, which is no longer condemned by religious authorities but seen as a "reflexive" personal choice.

Modernization processes and their effects on families include the following:

- Changes in production processes: these include economic growth generated by industrialization, by the transition from rural to urban work, and, today, by the development of pre-eminently market-based global service economies.

- Changes in demographic structure: rapid urbanization processes, longer life expectancy, lower birth rates and shrinking family size, reflected in changes in the population-age pyramid and family structure.

- New patterns of work and consumption: families have increasing access to the consumption of goods and services and there are changes in the forms of work: expansion of the industrial and service sectors, of paid female work, of informal-sector employment and of job instability.

- Massive but segmented access to social goods and services such as education, social security and health care: the coverage of the services is expanded, but there is also greater social fragmentation and inequality due to the different qualities of services supplied.

These changes in basic living conditions caused by the large-scale processes related to globalization and modernization -especially urbanization associated with industrialization, the growth of female employment, new consumption patterns and new forms of labour market participation- have a key influence on the organization of families and the way they perceive themselves.

With regard to modernity, ${ }^{7}$ other aspects are taken into account, such as the following:

- Promotion of social and individual freedom (individualization): this involves expansion of the rights of women and children; questioning of the patriarchal system within the family; profound changes in the areas of intimacy and sexuality; and a search for new identities (Giddens, 1992).

- Progress of the social dimension in the development of individual potential, to the detriment of the importance accorded to the family.

- "Reflexivity": This refers to the fact that most aspects of social activity are continuously being reassessed in the light of new information or knowledge (Giddens, 1991b). The family is not exempt from this reflexive approach, which changes people's courses of action and is particularly striking in the case of women (specifically in the feminist movement), representing the point at which male domination breaks down (Bourdieu, 2000).

- The spread of democratic attitudes: defence of diversity and increased tolerance; broadening of citizenship to include other social sectors such as ethnic groups, women, young people and children.

- Progressive secularization of collective action: as more and more people distance themselves from religion-based codes of behaviour, individual ethics are gaining force, especially with regard to the exercise of reproductive rights and sexual morality.

- Democratic representation in government, marked by the presence of different social attitudes and values.

- Spread of a formal and instrumental rationale.

\footnotetext{
${ }^{7}$ See Calderón, Hopenhayn and Ottone (1993); Giddens (1992, 1991a and 1991b); UNDP (1998) and Wagner (1997).
} 
- Generation of increasingly multicultural societies embracing diversity in life styles and family forms and structures.

In brief, modernity in the family is likely to be reflected in the exercise of democratic rights and autonomy among family members, together with a fairer distribution of labour (domestic and social), opportunities and family decision-making. This implies a new relationship based on asymmetries tempered by democratic principles (Salles and Tuirán, 1996).

Some elements of modernization processes in Latin America have not developed fully, resulting in small groups being included in social and material benefits while large population sectors are left out. Many of the changes associated with modernization have been carried out in a segmented fashion without being accompanied by the processes characteristic of modernity, especially as regards the cultural and identity dimensions of those changes.

Modernity is essentially a post-traditional order, characterized by increasing diversity of life styles and modes of living, with heterogeneous influences affecting habits, values, images, and modes of thought and entertainment. This is boosted by globalization processes, which have affected the social links between groups and have had powerful effects on the more personal aspects of our experience, where the security that traditions and customs used to provide has not been replaced by the certainty of rational knowledge (Giddens, 1991b). Accordingly, the changes in the family caused by the processes of modernization and modernity become a breaking point in the private-public dichotomy and give rise to emerging forms of family life that redefine the relationship between the family and society.

\section{The present Latin American context and its impact on families}

From a social and cultural standpoint, there are a number of worrying aspects in the current Latin American situation, where there has been a relative deterioration in economic and distributive terms which affects families differentially. The situation is made worse by the economic slowdown and the greater volatility of growth. In 2001, the gross domestic product grew by less than $0.5 \%$, and a figure of $1.1 \%$ is predicted for 2002 -far below the $6 \%$ growth rate that ECLAC deems necessary to reduce poverty in the region. As stated recently, Latin America has suffered two lost decades in terms of poverty and social inequality (Ocampo, 2001). Since the debt crisis and the structural adjustment programmes applied in the region, the burden of change has been disproportionately borne by poor families. Although the percentage of Latin American families living in poverty decreased from $41 \%$ to $35 \%$ between 1990 and 1999 , their absolute number grew by an additional 11.2 million people. In the year 2000, poverty affected 211.4 million Latin Americans, of whom over 89 million were indigent. Poverty continues to afflict children and adolescents relatively more. In $1999,59 \%$ of children between 0 and 5 years of age were poor, while $61 \%$ of those between 6 and 12 years of age were in that situation, reflecting the fact that poor families tend to have more children (ECLAC, 1999, 2000a and 2001).

At the same time, the productive system has generated severe inequality and heterogeneity as regards access to basic goods and services such as education, health care and social security. This is the result of an unequal supply of jobs, burgeoning privatization, more expensive basic services and increasing concentration of income. Although many Latin American countries enjoyed economic growth in the 1990s and were thus able to increase their social expenditure (which rose from US\$ 360 to US\$ 540 per capita between 1990 and 1999 in the region as a whole), generally speaking income distribution did not improve. In the same period, of the 16 Latin American countries for which data are available, only four saw their income distribution improve, another four registered no change, while eight suffered a deterioration. Costa Rica and Uruguay are the countries with the least income inequality in the region (ECLAC, 2001).

Alongside these processes, the expansion of the working-age population has generated simultaneous trends towards precarious employment and open unemployment in the region. Between 1990 and 1999 the number of unemployed grew by $10 \%$ per year to account for $8.6 \%$ of the work force by the end of the period. The rate was higher among urban population groups, where it reached $10.8 \%$, and the situation was aggravated by the fact that in some cases the average duration of unemployment also increased (ECLAC, 2001). Unemployment is higher among the poorer population segments, those with less education, young people and women. Another worrying aspect is the contradiction between the increase in structural unemployment and the economic growth registered, with all the damage that this causes to family security and stability. 
Recent trends also reveal the deteriorating situation and impoverishment of the middle-income groups. Faced with increasing unemployment, more and more family members (especially women, young people and children) are finding work in traditionally precarious and lowproductivity sectors. The entry of women into low-paid jobs offering them no chance of improving their employment prospects suggests that, while paid employment is a way of enhancing their living standards and gaining greater self-sufficiency, it has the disadvantage that it further increases the total workload borne by women, who have to divide their responsibilities between the family and their job, while receiving little support from their partner or from social institutions. ${ }^{8}$

In addition to this deterioration in economic and labour aspects, there has been a revolution in expectations, fuelled by the mass media, which has increased the sense of frustration at the widening gap between the growing desires for consumption and the real possibility of obtaining the goods desired. Inequality in the region is growing and differences are widening, and this severely hinders the possibilities of the social integration of families and further aggravates the sources of differences between them.

\section{III}

\section{The main changes in Latin American families}

Latin American families have been changing both in image and in reality. Academics and policy-makers alike agree that families have been confronting crucial changes, ${ }^{9}$ including demographic shifts, growth in the number of households headed by women, and an increasing number of women entering the labour market.

There have also been changes in symbolic aspects, reflected in new types of families and family relationships, in the context of societies undergoing continuous processes of change that question traditional family roles and raise new challenges and tensions for their members.

It has been asserted that all three dimensions of the classic definition of the family -sexuality, procreation and cohabitation-have changed profoundly and have begun to evolve in different directions, resulting in a growing multiplicity of family and cohabitation models (Jelin, 1998). It is generally agreed that most of the changes in family structure are gradual and are influenced by family location (urban versus rural), social class and the various experiences that Latin American societies have gone through (Salles and Tuirán, 1997). Other changes have been very dynamic, however, including the extremely rapid evolution of the

\footnotetext{
${ }^{8}$ This is particularly true of poorer women. Mothers with higher incomes can hire domestic servants for their homes or private services to take care of their children.

${ }^{9}$ For more statistical data on households and families, see Arriagada (2001).
}

social roles of women both within and outside the family, the increase in their labour market participation, and the growing number of households headed by women.

\section{Demographic changes}

The first demographic transition -involving a reduction in mortality and fertility rates and an increase in life expectancy- has had major effects on the family, particularly in Latin America. Longer life expectancy has lengthened the duration of life as a couple, ${ }^{10}$ while also increasing the number of single-person households, families made up of older adults and households with no children. ${ }^{11}$

Average family size has shrunk because couples are having fewer children and births are being spaced more widely apart. The number of multi-generational families is falling, while single-person households are on the rise. Migration, which may occur for a variety of reasons (economic considerations, armed conflict, among others), is another factor.

\footnotetext{
${ }^{10}$ In Mexico it is estimated that husband/wife roles can span up to 40 years of peoples' lives (Ariza and De Oliveira, 2001). In countries such as Argentina, Uruguay and Chile the period could be even longer, barring separation or divorce.

${ }^{11}$ At present, one in every four Latin American households contains at least one older adult (ECLAC, 2000a); this increase in the number of older persons means an increase in the care-giving work performed by women in their homes.
} 
By the 1990s, fertility rates (including those among adolescents) had fallen in most Latin American countries. Since then, however, they have stabilized and in some cases (Argentina, Chile, Panama and Uruguay) there has been an increase in adolescent fertility rates, which reflects the fact that different countries are at different stages in the demographic transition. The highest adolescent fertility rates are in the poorest population groups, among teenagers with little schooling, in rural areas and in areas with high concentrations of indigenous people (ECLAC, 2000b; Guzmán and others, 2001).

In some of the region's socially more developed countries (such as Argentina, Chile and Uruguay), models of sexual, nuptial and reproductive behaviour that are widespread in developed countries are beginning to take root among higher-income and more educated social groups. These include later marriage and reproduction among young people with high levels of schooling, and higher rates of divorce and cohabitation among middle-income groups. ${ }^{12}$ The consolidation of these patterns in Europe has led some authors to suggest that they represent a second demographic transition.

This second transition is associated with a profound change in values, closely related to Giddens's concept of late modernity (Giddens, 1991a and 1992), although demographers studying this subject have preferred to associate it with "post-materialist values" (Inglehart, cited by Van de Kaa, 2001) and, more recently, with post-modernization and post-modernity (Van de Kaa, 2001). Apart from fertility indices that are well below replacement levels, this second transition includes the following features: i) an increase in celibacy and voluntarily childless couples; ii) postponement of first union; iii) later birth of the first child; iv) consensual unions increasingly seen as an alternative to marriage; v) an increase in the number of children born and raised out of wedlock; vi) greater frequency of marital breakdown (divorce); and vii) diversification of family structures.

Some of these features have a long history in Latin America, and their existence has less to do with

\footnotetext{
${ }^{12}$ In Chile, for example, between 1980 and 1999 the average age at marriage rose from 26.6 to 29.4 years among men and from 23.8 to 26.7 years of age among women. During the same period the number of marriages decreased, annulments increased, birth rates diminished and the number of children born out of wedlock rose. In $1999,47.7 \%$ of children were born out of wedlock, whereas in 1990 the figure had been only $34.3 \%$ (SERNAM, 2001).
}

modernity than with exclusion and even with traditionalism. This is true of consensual unions and marital abandonment, for example. In short, certain socio-demographic phenomena affecting Latin American families conceal differentiated and specific determinants, directions and consequences that depend on the socioeconomic group in which they occur.

\section{New types of families}

New family structures, such as childless couples and households with no conjugal nucleus, have emerged in Latin America alongside traditional forms, while households headed by women continue to grow in number. This may reflect the existence of new structures typical of modernity. Box 1 describes the types of families and households that can be identified on the basis of the data from household surveys.

With regard to the household types that can be construed from the survey data, between 1986 and 1990 the vast majority of households were nuclear, followed in order of frequency by extended families and singleperson households (the latter category having grown in all the countries except Panama), households with no nucleus, and lastly composite families (table 1). The data for extended families may conceal other secondary nuclear families involving offspring that have not yet managed to set up their own families, especially adolescent mothers, for example.

As separation and divorce have become more common, blended families have emerged as a new and growing phenomenon in the region. These result from divorce, separation, widowhood or breakup of cohabitation and the formation of new unions. The existing statistical categories are unable to measure the number of families of this type, however, and they are considered as two-parent nuclear families. ${ }^{13}$

Although nuclear families continue to be the norm in Latin America in both urban and rural areas, the wide variety of situations that they reflect make it desirable to study the internal configuration of such households in greater depth. Although two-parent nuclear households are still the most common form, singleparent families - usually headed by women-are on the

\footnotetext{
${ }^{13}$ Blended, reconstituted, reformed or new families are difficult to quantify through household surveys, since the questionnaires generally do not ask whether the family concerned corresponds to a first or subsequent marriage, and they make no distinction between children and stepchildren. Such households are therefore recorded as two-parent nuclear families.
} 
Box 1

FAMILY AND HOUSEHOLD TYPES CONSTRUED FROM HOUSEHOLD SURVEYS

The following types of households are distinguished in this study:

- Single-person households (households consisting of only one person);

- Non-nuclear households (i.e., without a conjugal nucleus or parent-child relationship, although other kinship ties may exist).

The types of families distinguished include:

- Nuclear families (one or both parents present, with or without children);

- Extended families (one or both parents present, with or without children and other relatives or non-relatives); and

- Composite families (one or both parents, with or without children, with or without other relatives and nonrelatives).

Families may be either single-parent (i.e., with only one parent present, usually the mother), or two-parent families (both parents present); they may or may not have children.

TABLE 1

Latin America (17 countries): Types of urban households, around 1986 and 1999

(As a percentage of total households)

\begin{tabular}{|c|c|c|c|c|c|c|c|}
\hline \multirow[t]{2}{*}{ Country } & & \multicolumn{5}{|c|}{ Types of households and families } & \multirow[b]{2}{*}{ Total } \\
\hline & & Single-person & Nuclear & Extended & Composite & $\begin{array}{l}\text { Non-nuclear } \\
\text { households }\end{array}$ & \\
\hline \multirow[t]{2}{*}{ Argentina } & 1986 & 11.3 & 71.9 & 12.3 & 0.4 & 4.1 & 100.0 \\
\hline & 1999 & 15.5 & 67.2 & 11.7 & 0.4 & 5.2 & 100.0 \\
\hline \multirow[t]{2}{*}{ Bolivia } & 1994 & 7.6 & 71.2 & 15.7 & 1.7 & 3.8 & 100.0 \\
\hline & 1999 & 8.7 & 71.5 & 15.4 & 0.3 & 4.1 & 100.0 \\
\hline \multirow[t]{2}{*}{ Brazil } & 1987 & 6.9 & 76.8 & 11.2 & 1.1 & 4.0 & 100.0 \\
\hline & 1999 & 9.2 & 69.2 & 16.8 & 0.8 & 4.0 & 100.0 \\
\hline \multirow[t]{2}{*}{ Chile } & 1987 & 6.4 & 61.6 & 26.0 & 1.6 & 4.5 & 100.0 \\
\hline & 1998 & 7.5 & 65.1 & 22.1 & 1.1 & 4.2 & 100.0 \\
\hline \multirow[t]{2}{*}{ Colombia } & 1986 & 5.0 & 68.6 & 18.8 & 2.3 & 5.3 & 100.0 \\
\hline & 1999 & 6.7 & 60.1 & 25.2 & 2.3 & 5.7 & 100.0 \\
\hline \multirow[t]{2}{*}{ Costa Rica } & 1988 & 4.4 & 68.2 & 19.3 & 3.2 & 4.9 & 100.0 \\
\hline & 1999 & 6.2 & 68.4 & 18.4 & 2.5 & 4.5 & 100.0 \\
\hline Ecuador & 1999 & 6.0 & 63.0 & 22.9 & 3.5 & 4.6 & 100.0 \\
\hline El Salvador & 1997 & 7.1 & 55.0 & 28.7 & 2.5 & 6.7 & 100.0 \\
\hline Guatemala & 1998 & 4.3 & 63.2 & 26.6 & 1.8 & 4.1 & 100.0 \\
\hline \multirow{2}{*}{ Honduras } & 1994 & 3.4 & 58.2 & 29.1 & 4.7 & 4.7 & 100.0 \\
\hline & 1999 & 5.5 & 53.9 & 29.9 & 5.2 & 5.5 & 100.0 \\
\hline \multirow[t]{2}{*}{ Mexico } & 1984 & 5.2 & 70.3 & 19.2 & 0.7 & 4.6 & 100.0 \\
\hline & 1998 & 7.5 & 72.8 & 16.7 & 0.2 & 2.8 & 100.0 \\
\hline Nicaragua & 1997 & 4.4 & 57.0 & 29.0 & 4.7 & 4.9 & 100.0 \\
\hline \multirow[t]{2}{*}{ Panama } & 1986 & 12.0 & 61.0 & 14.2 & 5.9 & 6.9 & 100.0 \\
\hline & 1999 & 9.6 & 58.4 & 24.6 & 1.4 & 6.0 & 100.0 \\
\hline \multirow[t]{2}{*}{ Paraguay } & 1986 & 6.0 & 53.0 & 28.7 & 7.5 & 4.8 & 100.0 \\
\hline & 1999 & 8.8 & 57.7 & 24.2 & 3.7 & 5.6 & 100.0 \\
\hline Dominican Rep. & 1999 & 8.3 & 53.9 & 29.8 & 0.7 & 7.3 & 100.0 \\
\hline \multirow[t]{2}{*}{ Uruguay } & 1986 & 11.9 & 63.3 & 17.2 & 1.4 & 6.2 & 100.0 \\
\hline & 1999 & 16.6 & 62.7 & 14.5 & 1.2 & 5.0 & 100.0 \\
\hline \multirow[t]{2}{*}{ Venezuela } & 1986 & 4.5 & 56.4 & 31.2 & 2.6 & 5.3 & 100.0 \\
\hline & 1999 & 5.2 & 56.2 & 31.8 & 2.2 & 4.6 & 100.0 \\
\hline
\end{tabular}

Source: ECLAC, on the basis of special tabulations of household surveys of the countries concerned. 
increase, as are childless nuclear families, usually consisting of older adults whose children have already set up their own homes. Statistical categories need to be altered to capture new social realities, especially changes in family structures, and specific modules are also needed to take account of historical situations reflecting different family cultures, as in Caribbean countries (box 2).

Regardless of their magnitude and statistical invisibility, new family structures (e.g., blended families, childless families, non-nuclear families and single-person households) are beginning to appear more and more often in the media, and this is changing society's image of the range of family types to be found in the region and suggesting new possibilities for building families in the future.

\section{Households headed by women}

Here too, the analytical difficulties raised by the concept of "head of household" as defined in censuses and household surveys are worthy of note. The concept of the household includes the concept of family, so that while all families are households, not all households are families. For a household to be considered a "family", at least one of its members needs to have a kinship relationship with the person claiming to be the head of the household surveyed.
Traditionally, census and household survey measurements have considered the head of household to be the person in the conjugal nucleus who is recognized as such by the other members, regardless of the actual situation with respect to decision-making or economic contribution. The fact that censuses and surveys do not admit shared headship leads to a sexist bias, because when there is both a head of household and a spouse, the man is considered the head of the household and the wife the spouse, yet when the household is headed by a woman, the assumption is that there is no male spouse.

Thus, the subjective nature of the definition reflects cultural expectations regarding decision-making authority or ownership of assets, mediated through social mores that categorize men's and women's roles as economic actors and breadwinners and as care-givers and child-raisers, respectively (Gammage, 1998).

Three types of household can therefore be distinguished, depending on the sex of the head of household and the presence or otherwise of a spouse: two-parent, single-parent headed by a man, and singleparent headed by a woman. ${ }^{14}$ Given the shortcomings in the definition of head of household mentioned above, a number of suggestions for avoiding a sexist bias have proposed simultaneous consideration of de jure and de facto female/male headship (Gammage, 1998), thereby linking up the de jure concept normally used in censuses

Box 2

CARIBBEAN FAMILY TYPES

Unlike many societies, in the Commonwealth Caribbean countries marriage is not the only type of family union prevailing, and it does not necessarily indicate the start of child-rearing. At least three types of family union can be identified:

1. Marriage, which involves a legal commitment and cohabitation;

2. Consensual unions, in which the partners share a common home but there is no legal commitment between them; and

3. Unions involving regular visits ("visiting unions"), in which there is a regular sexual relationship but neither cohabitation nor legal commitment. This type of union should be distinguished from casual relationships, where there is no stable relation.

The raising of children may be a feature of any of these situations.

Source: Massiah, 1990.

${ }^{14}$ By definition, only in the nuclear conjugal two-parent case is a
childless household classified as a family. In the absence of either
a husband or wife, the household is only considered a single-parent
family when it includes children of the head of the household. Non- family households include single-person and non-nuclear households headed by either a man or a woman. It is recognized, however, that many non-nuclear households do involve kinship relations. 
and surveys with the de facto concept determined on the basis of who makes the greater economic contribution to family income. When this is done, it reveals some interesting relations between the two types of female-headed household.

A comparison based on the de jure and de facto criteria shows that women are more "invisible" in the traditional manner of defining the head of household. In all Latin American countries the percentage of households whose main economic contribution is provided by a woman is greater than the percentage recognized as headed by women, except in Nicaragua, where the figures are the same (table 2).

The number of households headed by women (whether de jure or de facto) has continued to grow steadily since the early $1990 \mathrm{~s},{ }^{15}$ so that this group now accounts for between a quarter and one-third of all households, depending on the country. According to

${ }^{15}$ Between 1990 and 1999, the number of households headed by women increased in 14 countries and remained constant in two (ECLAC, 2001, p. 151). the de jure criterion, the highest percentages of households headed by women were reported in Nicaragua (35\% in 1998) and in the Dominican Republic and Uruguay (31\% in 1999). The incidence of extreme poverty is also consistently higher among such households: in 13 out of 17 countries, indigence rates were higher in households headed by women than in households generally. In Costa Rica and the Dominican Republic, over half of all indigent households were headed by women. It is remarkable that analyses, measures and policies fail to consider the situation of households with de facto female headship, which clearly demonstrates the breakdown of the traditional family model in which the man plays the role of head of household and breadwinner.

\section{The family life cycle}

Latin America has seen profound changes in the distribution of families at each stage of the family life cycle. This is the result of major demographic changes, especially the fall in birth rates that occurred during

TABLE 2

Latin America (17 countries): Households headed by women on a de jure and de facto basis

(Percentages)

\begin{tabular}{|c|c|c|c|c|}
\hline Country & Year & $\begin{array}{l}\text { Households headed by women } \\
\text { on a de facto basis } \\
\text { (in which a woman is the main } \\
\text { economic provider) } \\
\text { (1) }\end{array}$ & $\begin{array}{l}\text { Households headed } \\
\text { by women de jure } \\
\text { (2) }\end{array}$ & $\begin{array}{c}\text { Difference } \\
(1-2) \\
\text { (in \% points) }\end{array}$ \\
\hline Argentina & 1999 & 33 & 27 & +6 \\
\hline Bolivia & 1999 & 28 & 21 & +7 \\
\hline Brazil & 1999 & 33 & 25 & +8 \\
\hline Chile & 1998 & 28 & 24 & +4 \\
\hline Colombia & 1999 & 36 & 29 & +7 \\
\hline Costa Rica & 1999 & 30 & 28 & +2 \\
\hline Ecuador & 1999 & 27 & 20 & +7 \\
\hline El Salvador & 1997 & 38 & 31 & +7 \\
\hline Guatemala & 1998 & 30 & 24 & +6 \\
\hline Honduras & 1999 & 36 & 30 & +6 \\
\hline Mexico & 1998 & 27 & 19 & +8 \\
\hline Nicaragua & 1998 & 35 & 35 & 0 \\
\hline Panama & 1999 & 30 & 27 & +3 \\
\hline Paraguay (Asunción) & 1999 & 33 & 27 & +6 \\
\hline Dominican Rep. & 1997 & 32 & 31 & +1 \\
\hline Uruguay & 1999 & 36 & 31 & +5 \\
\hline Venezuela & $1999^{\text {a }}$ & 30 & 27 & +3 \\
\hline
\end{tabular}

Source: ECLAC, on the basis of special tabulations of household surveys of the countries concerned and www.eclac.cl/mujer/proyectos/ perfiles/comparados/hogar7.htm

a Nationwide total. 
the 1970s. Thus, although families whose eldest child is under 12 years of age are still the largest group, the number of families whose eldest child is over 13 has increased faster (Arriagada, 1998). Another important phenomenon affecting the length of the family life cycle and the number of years of marriage or cohabitation is increased life expectancy at birth. This explains the increase in the number of households consisting of a single elderly adult, especially widows, in countries which are at an advanced stage of the transition.

For 1995/2000, life expectancy in Latin America was estimated at 73 years for women and 67 years for men, albeit with large variations between countries at different stages in the demographic transition. Between $1985 / 1990$ and 1990/2000, the average life expectancy for Latin American men and women increased by three years, with the lowest figure corresponding to Haiti (57 years) and the highest to Costa Rica (77 years). There is also a 20-year difference between Haiti and Costa Rica in the life expectancy of women, estimated at 59 and 79 years respectively (CELADE, 1999).

Bearing in mind that the genetic potential of women causes them to live longer than men, the wide range of differences between the life expectancy of men and women in Latin American countries is somewhat surprising. As suggested by Sen (1991), inter-country differences in the life-expectancy of men and women probably reflect levels of abandonment of women and discrimination against them in terms of basic health care and nutrition. Estimates for 1995/2000 suggest that the best living conditions for women are to be found in Brazil, where there is an eight-year difference between women's and men's life expectancy. The worst conditions are in Bolivia, where the difference is only three years. ${ }^{16}$

Other aspects relating to changes in the stages of the family cycle include a reduction in the number of children and an increase in the age of marriage in nearly all countries that have such information available. There have also been slight increases in the ages at which the first sexual encounter, the first union and the birth of the first child occur (ECLAC, 2000b). These developments correspond to the second demographic

\footnotetext{
${ }^{16}$ Normally, the difference in life expectancy between the sexes in developed European countries is around six years. The larger difference in Brazil can partly be explained by higher mortality among the young male population due to accidents and violent deaths (homicides). In 1994 the male death rate from homicides was 54.8 per thousand inhabitants, whereas the equivalent figure for women was 5.2 (Arriagada and Godoy, 1999).
}

transition. Here again it is worth noting that women with relatively more education tend to postpone their first sexual relationship, first union and first child. Some countries in the region report that a large percentage of women between 15 and 49 years old did not want to have more children when they last became pregnant. This proportion is much higher among women belonging to the poorest strata (income quintile 1) than those in the wealthiest (quintile 5). Bolivia and Peru display notably large differences between quintiles 1 and 5 (33\% and $32 \%$, respectively), which suggests a deficit area in the coverage of reproductive health care services among the poorest female population groups (table 3).

\section{Poverty and inequality among families}

Between the 1980s and 1999 average household size decreased in all the Latin American countries. ${ }^{17}$ The heterogeneity of the individual country situations is explained by their different histories and the fact that they are at different stages in the demographic transition. Uruguay has the smallest average household size (3.2 persons in 1999), while Honduras is at the opposite extreme with 4.8 persons per household. Household size also varies greatly with income. The smallest difference between the poorest and wealthiest quintiles was 1.4 persons in the Dominican Republic and 1.5 in Costa Rica. The largest differences in household size were found in Guatemala and Mexico (2.8 and 2.7 persons, respectively). Countries at different stages in the demographic transition, such as Costa Rica and the Dominican Republic, display very little variation between income strata, suggesting that these two countries have more widely shared cultural patterns in terms of ideal family size, and probably more equal access to knowledge and use of contraceptive methods across income groups. Possibly this is not the case in Guatemala and Mexico, where there are large differences in family size between the wealthier and poorer population segments, as well as major cultural and ethnic diversity.

The structure of Latin American families varies greatly according to income level. For example, to set up a single-person household requires a level of economic resources not available to everyone who

\footnotetext{
${ }^{17}$ In the 17 Latin American countries for which data are available, average household size decreased between 1986 and 1999. Although household size is larger in the poorest quintile, it too decreased during this period (Arriagada, 2001).
} 
TABLE 3

Latin America (7 countries): Percentage of women between 15 and 49 years of age who did not want to have more children when they last became pregnant, by family income quintiles, 1996

(Percentages)

\begin{tabular}{|c|c|c|c|c|c|}
\hline \multirow[t]{2}{*}{ Country } & \multicolumn{5}{|c|}{ Family income quintiles } \\
\hline & Year & Total & Q1 & Q5 & Q1 - Q5 \\
\hline Bolivia & 1997 & 33.3 & 46.7 & 13.6 & 33.1 \\
\hline Brazil & 1996 & 23.2 & 29.4 & 17.8 & 11.6 \\
\hline Colombia & 1995 & 22.6 & 32.8 & 14.7 & 18.1 \\
\hline Guatemala & 1995 & 13.5 & 14.6 & 13.9 & 0.7 \\
\hline Haiti & 1995 & 36.2 & 34.5 & 31.5 & 3.0 \\
\hline Nicaragua & 1998 & 18.3 & 20.3 & 13.7 & 6.6 \\
\hline Peru & 1996 & 36.9 & 51.8 & 19.5 & 32.3 \\
\hline Dominican Republic & 1996 & 10.8 & 16.3 & 5.3 & 11.0 \\
\hline
\end{tabular}

Source: ECLAC (2000b).

would like to live alone. At the other extreme, a larger percentage of poor families are extended and composite. The number of children marks the difference between nuclear families in the poorest quintile and those from the wealthiest one. While no direct temporal causeeffect relationship can be established (Does having more children prevent families from overcoming poverty, or does poverty cause people to have more children?), there is a significant correlation between family income and family structure. This correlation has two dimensions: poor households usually have a larger number of economically dependent children, yet they also tend to have fewer economic providers.

The incidence of poverty also varies according to the stage of the family life cycle. A typology has been developed of the various stages through which family households can pass. Although the classification is basically empirical and corresponds to a cross-section in time, it is considered to come close to the conceptual differences between the initial stage of starting a family (children start arriving), the consolidation stage (childbearing ceases), and finally the departure of the children (they "leave the nest" or set up their own households). Unlike an earlier typology, ${ }^{18}$ this one is based on the age of the youngest child, since younger children generate more domestic chores in the home (box 3 and table 4). ${ }^{19}$

\footnotetext{
18 See Arriagada, 1997.

19 The existence of blended families complicates this typology, because families that have interrupted one family life cycle (as a result of separation and divorce) and started another (new unions) may have families with children that are much older or much younger.
}

The majority of Latin American families are in the expansion and growth stage, with youngest children under 12 years of age. Countries in advanced stages of the demographic transition, such as Argentina, Chile, Panama and Uruguay, have more families located in the consolidation and departure phase, where the youngest child is 13 or older, or in the "empty nest" category, i.e., older couples without children. These trends can be assimilated to late modernity.

The highest rates of poverty in all countries (with the sole exception of Bolivia) occur in the expansion and growth stage, where the youngest children are 12 years old or under. In Bolivia, poverty is more prevalent among families in the initial cycle, i.e., with children under six years of age (table 5). This information should alert policy-makers to aspects that need to be considered in public policies to reduce poverty.

\section{Transformation of the social roles of women}

It has been argued that changes in the organization of the economy, in processes of constructing individual identity, in culture, and in newly appropriated ideas on liberty, autonomy, rights and political participation have all influenced the system of gender relations. Changes in the daily interaction between men and women, and the pressure exerted by women's organizations on public agendas and political power, have helped to undermine the rules that traditionally regulated behaviour in the domains of the family, intimacy and sexuality, and the other key social institutions of modern life (Guzmán, 2002).

In particular, the massive entry of women into the labour force has changed traditional patterns of home life in Latin America. Taking the region as a whole, 
Box 3

FAMILY LIFE CYCLE TYPOLOGY, BASED ON HOUSEHOLD SURVEYS

1. Young couple without children: couples who have not had children, in which the woman is under 40 years of age.

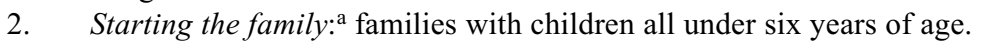

3. Expansion or growth cycle: families whose youngest children are 12 years old or younger.

4. Consolidation and departure: families whose youngest children are 13 or older.

5. Older couple without children (empty nest): couples without children, where the woman is over 40 years of age.

a By way of example, the "starting the family" stage only includes families with children all under 6; if a family has one child aged 5 and another aged 11, it will be classified in the "expansion or growth" stage.

TABLE 4

Latin America (15 countries): Family life cycle in urban areas, 1999

(Percentages)

\begin{tabular}{|c|c|c|c|c|c|c|c|}
\hline \multirow[b]{2}{*}{ Country } & \multicolumn{7}{|c|}{ Stage in family life cycle ${ }^{a}$} \\
\hline & Year & $\begin{array}{l}\text { Young couple } \\
\text { with no children }\end{array}$ & $\begin{array}{l}\text { Start of } \\
\text { family }\end{array}$ & $\begin{array}{l}\text { Expansion } \\
\text { or growth }\end{array}$ & $\begin{array}{l}\text { Consolidation } \\
\text { and departure }\end{array}$ & $\begin{array}{c}\text { Older couple } \\
\text { without children }\end{array}$ & Total \\
\hline Argentina & 1999 & 4.0 & 10.4 & 34.5 & 38.2 & 12.8 & 100.0 \\
\hline Bolivia & 1999 & 2.5 & 14.4 & 50.9 & 27.5 & 4.9 & 100.0 \\
\hline Brazil & 1999 & 5.7 & 13.4 & 36.7 & 35.7 & 8.5 & 100.0 \\
\hline Chile & 1998 & 3.0 & 10.2 & 39.0 & 39.5 & 8.2 & 100.0 \\
\hline Colombia & 1999 & 3.9 & 13.2 & 40.6 & 37.1 & 5.1 & 100.0 \\
\hline Costa Rica & 1999 & 4.3 & 10.6 & 42.3 & 36.2 & 6.5 & 100.0 \\
\hline Ecuador & 1999 & 3.7 & 13.1 & 43.5 & 33.5 & 6.2 & 100.0 \\
\hline Guatemala & 1998 & 2.1 & 10.1 & 47.6 & 34.4 & 5.9 & 100.0 \\
\hline Honduras & 1999 & 3.4 & 14.0 & 48.3 & 31.2 & 3.1 & 100.0 \\
\hline Mexico & 1998 & 3.8 & 13.4 & 44.0 & 33.4 & 5.4 & 100.0 \\
\hline Panama & 1999 & 4.1 & 10.3 & 36.2 & 41.8 & 7.6 & 100.0 \\
\hline Paraguay & 1999 & 3.7 & 15.1 & 47.7 & 28.2 & 5.2 & 100.0 \\
\hline Dominican Republic & 1997 & 6.8 & 15.5 & 38.4 & 34.0 & 5.3 & 100.0 \\
\hline Uruguay & 1999 & 4.2 & 8.9 & 29.6 & 38.5 & 19.0 & 100.0 \\
\hline Venezuela $^{\mathrm{b}}$ & 1999 & 2.7 & 9.7 & 44.0 & 39.2 & 4.3 & 100.0 \\
\hline
\end{tabular}

Source: ECLAC, on the basis of special tabulations of household surveys of the countries concerned.

a Start of family: families with children under six years of age.

Expansion or growth: families whose youngest children are 12 years old or younger.

Consolidation and departure: families whose youngest children are 13 or older.

${ }^{\mathrm{b}}$ Nationwide total.

female activity rates rose from $39 \%$ in 1990 to $44.7 \%$ in 1998 (Abramo, Valenzuela and Pollack, 2000), albeit with big differences according to country, area of residence, age and educational level. Although the highest employment rates are seen among women with more education, as Latin American households grapple with ever-greater financial difficulties less-educated women are also entering the labour market in ever larger numbers. As a result, more family members now contribute to household income (including women, teenagers and children), marking the demise of the single-breadwinner system in the most socially vulnerable households. Increased labour market participation by women - whether rich or poor - offers them the chance of greater autonomy and participation in other social domains.

Thus, although demographic changes have been very gradual, women have continued to join the labour market at an ever-increasing rate. A number of studies have shown that during the 1990s the largest percentage of new female entrants have been women in the most demanding stages of the reproductive cycle (i.e., when 
TABLE 5

Latin America (15 countries): Incidence of poverty in urban areas, by stage of family life cycle, 1999

\begin{tabular}{|c|c|c|c|c|c|c|c|}
\hline \multirow[b]{2}{*}{ Country } & \multicolumn{7}{|c|}{ Stage in family life cycle ${ }^{a}$} \\
\hline & Year & $\begin{array}{c}\text { Young couple } \\
\text { with no children }\end{array}$ & $\begin{array}{l}\text { Start of } \\
\text { family }\end{array}$ & $\begin{array}{l}\text { Expansion } \\
\text { or growth }\end{array}$ & $\begin{array}{l}\text { Consolidation } \\
\text { and departure }\end{array}$ & $\begin{array}{l}\text { Older couple } \\
\text { without children }\end{array}$ & $\begin{array}{c}\text { Total } \\
\text { poverty }\end{array}$ \\
\hline Argentina & 1999 & 1.7 & 18.5 & 32.6 & 12.8 & 9.3 & 19.4 \\
\hline Bolivia & 1999 & 19.0 & 54.2 & 53.8 & 30.0 & 28.5 & 45.2 \\
\hline Brazil & 1999 & 13.9 & 38.4 & 41.7 & 18.9 & 9.6 & 28.8 \\
\hline Chile & 1998 & 4.7 & 19.9 & 27.4 & 12.3 & 6.2 & 18.2 \\
\hline Colombia & 1999 & 16.9 & 53.8 & 59.6 & 37.3 & 29.6 & 47.4 \\
\hline Costa Rica & 1999 & 3.8 & 10.7 & 20.8 & 11.6 & 20.8 & 15.6 \\
\hline Ecuador & 1999 & 32.1 & 59.5 & 68.6 & 53.6 & 50.1 & 59.9 \\
\hline Guatemala & 1998 & 17.7 & 35.6 & 49.8 & 32.2 & 34.0 & 40.7 \\
\hline Honduras & 1999 & 46.8 & 67.0 & 73.7 & 63.5 & 58.7 & 68.2 \\
\hline Mexico & 1998 & 14.8 & 32.5 & 42.8 & 25.8 & 23.7 & 33.7 \\
\hline Panama & 1999 & 4.4 & 22.8 & 34.2 & 14.4 & 14.6 & 22.0 \\
\hline Paraguay & 1999 & 12.0 & 45.0 & 56.2 & 32.7 & 34.6 & 45.1 \\
\hline Dominican Rep. & 1997 & 9.5 & 29.6 & 42.6 & 30.0 & 25.2 & 33.1 \\
\hline Uruguay & 1999 & 1.6 & 9.9 & 14.8 & 3.5 & 1.2 & 6.9 \\
\hline Venezuela $^{\mathrm{b}}$ & 1999 & 13.7 & 45.5 & 55.3 & 35.9 & 37.0 & 44.8 \\
\hline
\end{tabular}

Source: ECLAC, on the basis of special tabulations of household surveys of the countries concerned.

a Start of family: families with children under six years of age.

Expansion or growth: families whose youngest children are 12 years old or younger.

Consolidation and departure: families whose youngest children are 13 or older.

b Nationwide total.

they have small children). The economic contribution of women who undertake paid work helps keep many households above the poverty line (ECLAC, 1995; Arriagada, 1998).

The contribution of an additional income marks the difference between households in the poorest and wealthiest quintiles. Households with more than one breadwinner most often consist of two-parent families, extended families or composite families. By their very nature, a smaller percentage of single-parent families have multiple income-earners, since in this case additional incomes can only come as a result of sons or daughters entering the labour market. In the 1990s, nearly all countries saw an increase in the number of households with more than one breadwinner, both in the poorer quintiles and among those that were better off.

Participation in public life is giving rise to new perceptions of women's roles and affords them greater autonomy with respect to their families. This cultural change can be seen in a tendency for motherhood to become a matter of choice; later first marriages; lower fertility rates; conflicts between two-career couples, and the need to balance domestic chores with paid employment. As pointed out by Sen (1990 and 1991), the distribution of the co-benefits of the family is likely to be less unfavourable for women if: i) they can earn an income outside the home; ii) their work is recognized as productive (this is much easier to achieve with work outside the home); iii) they possess some economic resources and have assets they can fall back on; and iv) there is an understanding of the ways women are deprived of these benefits and a recognition of the possibilities for changing the situation.

These changes are not all in the same direction. Although total fertility has decreased, the demographic risks connected with the increase in teenage fertility and unplanned pregnancies persist, while new ones have also been generated (stemming from the spread of AIDS, for example). It has been noted that the persistence of demographic risks is due to a complex combination of traditional forms of behaviour (early union and pregnancy in the case of teenage fertility among lowincome groups), together with classical phenomena of social and economic exclusion, such as lack of access to contraceptive methods, in the case of unplanned pregnancy (CELADE, 2001), and other factors relating to youth culture. Women's autonomy -a key element in the measure of modernity achieved in education, in the economic domain and in political participation- is eclipsed in the face of demographic risks. 
The expansion of citizenship for Latin American women would also seem to be contradictory and elusive, for while there have been significant achievements in terms of political and civil rights, progress on economic, social and cultural rights has lagged behind. Despite these shortcomings, women's access to decisionmaking has improved at certain levels of the State machinery and also in political parties in some countries. Although information in this respect is sparse, there has also been a significant increase in women's participation at the technical levels of the public sector and in certain areas of the judiciary (ECLAC, 1999).

Rapid social, economic and cultural changes have an impact on family relationships, attitudes and social practices, since the new opportunities (such as greater autonomy, the possibility of choice with regard to childbearing, and economic independence for women) coexist with traditional patterns of behaviour, such as subjective dependency, teenage pregnancy and genderbased division of labour in domestic chores.

\section{Cultural changes}

Cultural concepts and images regarding male power continue to prevail in the social domain, along with behavioural patterns based on those images. This helps to explain the inconsistencies that exist between the traditional discourse and new family practices. Nonetheless, certain dimensions of modernity have been emerging, such as redefined conjugal roles, in which the principle of equality is gradually gaining acceptance, in keeping with the growing economic contribution made by women and children to the household. Changing parent-child relationships reflect a strengthening of the rights of the child and less emphasis on relations of hierarchy and submission. New individual choices are emerging, made possible by access to economic resources (non-nuclear and single-person households). The institution of the nuclear family centered on paternal authority and supported by the entire set of social institutions is being called into question by a number of interrelated processes, including: changes in the organization of work in a global information economy; higher levels of education and female labour market participation; increasing control over the spacing and frequency of pregnancies; circulation of people and ideas between different societies and lifestyles; and greater awareness among women themselves (Guzmán, 2002).

Incipient processes of "individualization" are also emerging, in which personal rights take precedence over family ones, and personal fulfilment overrides family interests. In these processes of cultural change, globalized images of different family types have fuelled the move towards individual rights and autonomy, along with changes in models of sexuality and intimacy, especially among adolescents, and a greater emphasis on peer culture (in which young people identify first and foremost with other young people). A recent study in Chile claims that young people see family relations as problematic. They believe this affects them negatively, and they blame parental attitudes for this. Authoritarianism, mistrust and a lack of care and affection are the most frequent complaints made by children about their family environment and situation (UNDP, 2002).

A number of changes in domestic relationships can be identified. A case study conducted in Mexico City and Monterrey shows that women today have greater decision-making power on reproductive issues (use of contraceptives, attending clinics) than in other areas of family life, compared to earlier studies. The gender-based division of labour for domestic chores shows little change; and domestic violence persists in a variety of forms, together with a strong tendency for men to restrict women's freedom to carry various types of activities. A large proportion of women still have to obtain permission to undertake paid work, join associations or visit friends and family, and there are still areas of exclusive male decision-making, such as the purchase of goods and where to live. Men and women have strikingly different perceptions of the various issues covered in the survey: in Mexico City, for example, the existence of domestic violence is perceived less clearly by men than by women - $16 \%$ compared to $33 \%$, respectively (García and De Oliveira, 2001).

A study in Argentina which analysed two generations of families with two providers concludes that "the division of labour has moved from the traditional model of segregated roles, to a transitional one ... The intergenerational transition has not been uniform, as paternity gained many more supporters than domesticity. In other words, men increased their participation in child care much more than in housekeeping chores, which remain largely a female preserve. Although women have not cut back on their major participation in domestic and maternal chores, they have begun to encroach on traditionally male activities in the home" (Wainerman, 2000, p. 149).

Latin American families have undergone major changes, although these have been more marked in some areas than in others. Patriarchal authority is being called into question, and very incipient democratic models of family reconstruction are emerging. This is 
increasingly necessary, since families provide psychological security and material well-being to their members in a world characterized by the individualization of work, the breakdown of civil society and the loss of legitimacy of the State. Nonetheless, the transition to new family forms entails a fundamental redefinition of gender relations in all societies (Castells, 1996). Unlike developed countries, Latin America displays glaring inequalities between families of different economic levels. Public-policy formulation therefore needs to consider the fact that

\section{IV}

\section{Conclusion}

Within the framework of the very sui generis modernization and modernity taking place in Latin America, this article has attempted to analyse a number of dimensions of the cultural, social and demographic changes that families in the region have undergone, against a general backdrop of inequality in terms of gender and class. Findings relating to family structures and home life cast doubt on the dominant traditional image, revealing the existence of a wide diversity of situations. Because of their systemic nature, gender inequities permeate the social fabric, so overcoming them requires changes in other mechanisms that perpetuate social inequality: hence the analytical importance of an approach that focuses on the overlap between this and other systems of inequality, relating to class, ethnic origin or life cycle (Ariza and De Oliveira, 2000; Salles and Tuirán, 1997).

In a context of modernization without modernity, family change does not follow a single line but unfolds along a variety of paths heading in different and sometimes opposite directions. The analytical frameworks used to study the subject reveal a number of limitations in approach and public-policy design, often due to the assumption that there is a single desirable family model.

In many discourses, the family is seen as the final bastion against the vicissitudes of modernity, overlooking the fact that the great demographic, social and economic changes it has undergone prevent it from adequately performing the functions demanded of it, which have also changed too. This suggests the existence of unresolved traditional problems, the family structures of poorer households prejudice their chances of escaping poverty, since they tend to be at the expansion stages in the family life cycle, with fewer economic providers and a larger number of members to provide for. These socioeconomic differences are compounded by gender and ethnic inequalities. These are fundamental issues when formulating policies and programmes aimed at democratizing Latin American families, which need to alter the current balance of men's and women's rights and obligations in the family domain. compounded by new challenges which families need additional cognitive, material and sociability resources to address (Güell, 1999). Modernity itself involves the possibility of accepting new forms of family structure and functioning that afford autonomy and reflexivity in decision-making for all members. The fact that these processes of reflexivity, which often take place privately, are not being adequately reflected in public debate further widens the gap between people's representations, discourses and practices.

With regard to family forms and functions in a Latin American setting of highly varied modernity, domestic gender inequalities are being rebuilt in the wake of the other changes taking place. These include a dual workload for women, the persistence of domestic violence, and more limited autonomy for women.

At the same time, the separation of sexuality from reproduction, so that motherhood is now a matter of choice, has increased women's possibilities of gaining access to better labour market opportunities (albeit often in precarious forms of employment) and taking part in social and political activities. On the other hand, the stages of the demographic transition tend to overlap even in a given country, depending on whether one is considering sectors of high socioeconomic level or extreme poverty. The social, economic and demographic changes taking place in Latin America display a number of basic pillars around which old forms of inequality are reproduced and new ones are created which require an integrated multidimensional approach to overcome.

(Original: Spanish) 


\section{Bibliography}

Abramo, L., M.E. Valenzuela and M. Pollack (2000): Equidad de género en el mundo del trabajo en América Latina. Avances y desafios cinco años después de Beijing, Santiago, Chile, International Labour Organisation (ILO).

Aguirre, R. and C. Fassler (1994), ¿Qué hombres? ¿Qué mujeres? ¿Qué familias?, Familias siglo XXI, "Ediciones de las Mujeres" series, No. 20, Santiago, Chile, IsIs International.

Ariza, M. and O. de Oliveira (1997): Formación y dinámica familiar en México, Centroamérica y el Caribe, Ibero-Amerikanisches Archiv Zeitschrift für Sozialwissenschaften und Geschichte, vol. 23, No. 1-2, Berlin, Sonderbruck.

(2000): Género, trabajo y familia: Consideraciones teórico-metodológicas, Mexico City, unpublished.

(2001): Familias en transición y marcos conceptuales en redefinición, Papeles de población, vol. 7, No. 28, Mexico City, Centro de Investigación y Estudios Avanzados de la Población, Universidad Autónoma del Estado de México (UAEM), April-June.

Arriagada, I. (1997): Políticas sociales, familia y trabajo en la América Latina de fin de siglo, "Políticas sociales" series, No. 21, LC/L.1058, Santiago, Chile, Economic Commission for Latin America and the Caribbean (ECLAC).

(1998): Latin American families: convergences and divergences in models and policies, CEPAL Review, No. 65, LC/G.2033-P, Santiago, Chile, Economic Commission for Latin America and the Caribbean (ECLAC).

(2001): Familias latinoamericanas. Diagnóstico y políticas públicas en los inicios del nuevo siglo, "Políticas sociales" series, No. 57, LC/L.1652-P, Santiago, Chile, Economic Commission for Latin America and the Caribbean (ECLAC), United Nations publication, Sales No. S.01.II.G.189.

Arriagada, I. and L. Godoy (1999): Seguridad ciudadana y violencia en América Latina: diagnóstico y políticas en los años noventa, "Políticas sociales" series, No. 32, LC/L.1179-P, Santiago, Chile, Economic Commission for Latin America and the Caribbean (ECLAC). United Nations publication, Sales No. S.99.II.G.24.

Bourdieu, P. (2000): La dominación masculina, Barcelona, Editorial Anagrama.

Calderón, F., M. Hopenhayn and E. Ottone (1993): Hacia una perspectiva crítica de la modernidad: las dimensiones culturales de la transformación productiva con equidad, Documento de trabajo, No. 21, Santiago, Chile, EClaC.

Castells, M. (1996), The Information Age: Economy, Society and Culture, vols. 1, 2 and 3, Blackwell Publishers Inc., Cambridge, Massachusetts.

CELAde (Latin American and Caribbean Demographic Centre) (1999), Latin America: Economically Active Population 19802025, Demographic Bulletin, vol. 32, No. 64, LC/DEM/ G.188; LC/G.2059, Santiago, Chile, July.

(2001): Presentation on socio-demographic vulnerability, Thirty-third Meeting of the Presiding Officers of the Regional Conference on Women in Latin America and the Caribbean, Port of Spain, 9 October.

Corporación Latinobarómetro (2000), Latinobarómetro 2000, Santiago, Chile.

DANE (Departamento Administrativo Nacional de Estadística) (1998), La familia colombiana en el fin de siglo, Santafé de Bogotá, Colombia.

ECLAC (1995): Social Panorama of Latin America, 1995, LC/
G.1886-P, Santiago, Chile. United Nations publication, Sales No. E.95.II.G.17.

(1999): Social Panorama of Latin America, 1998, LC/ G.2050-P, Santiago, Chile. United Nations publication, Sales No. E.99.II.G.4.

(2000a): Social Panorama of Latin America, 1999-2000, LC/G.2068-P, Santiago, Chile. United Nations publication, Sales No. E.00.II.G.18.

(2000b): Juventud, población y desarrollo: problemas, oportunidades y desafios, "Libros de la CEPAL" series, No. 59, LC/G.2113-P, Santiago, Chile. United Nations publication, Sales No. S.00.II.G.131.

(2001): Social Panorama of Latin America, 2000-2001, LC/G.2138-P, Santiago, Chile. United Nations publication, Sales No. E.01.II.G.141.

Fuller, N. (1997), Identidades masculinas. Varones de clase media en el Perú, Lima, Catholic University of Peru/Fondo Editorial.

Gammage, S. (1998): The Gender Dimension of Household Poverty: Is Headship Still a Useful Concept?, Washington, D.C., International Center for Research on Women (ICRW), unpublished. This text was presented in the same year at the Twenty-first International Congress of the Latin American Studies Association (LASA), held in Chicago.

García, B. and O. De Oliveira (2001), Las relaciones intrafamiliares en la ciudad de México y Monterrey: visiones masculinas y femeninas, paper presented at the Twenty-third International Congress of the Latin American Studies Association (LASA), Washington, D.C., 6-8 September.

Giddens, A. (1991a), The Consequences of Modernity, Stanford University Press.

(1991b): Modernity and Self-Identity: Self and Society in the Late Modern Age, Stanford University Press.

(1992): The Transformation of Intimacy: Sexuality, Love and Eroticism in Modern Societies, Stanford University Press.

Güell, P. (1999): Familia y modernización en Chile, paper presented at the Comisión de Expertos en Temas de Familia, Santiago, Chile, National Women's Service (SERNAM), December.

Guzmán, J.M. and others (2001): Diagnóstico sobre salud sexual y reproductiva de adolescentes en América Latina y el Caribe, Mexico City, United Nations Population Fund (UNFPA).

Guzmán, V. (2002), Las relaciones de género en un mundo global, "Mujer y desarrollo" series, No. 38, LC/L.1729-P, Santiago, Chile, Economic Commission for Latin America and the Caribbean (ECLAC). United Nations publication, Sales No. S.02.II.G.40.

Humphries, J. (ed.) (1999), Special issue on the family: Introduction, Cambridge Journal of Economics, vol. 23, No. 5, Oxford, Oxford University Press, September.

Jelin, E. (1994): Las familias en América Latina, Familias siglo XXI, "Ediciones de las Mujeres" series, No. 20, Santiago, Chile, ISIs International.

(1998), Pan y afectos. La transformación de las familias, Buenos Aires, Fondo de Cultura Económica.

Massiah, J. (1990): Defining women's work in the Commonwealth Caribbean, in I. Tinker, Persistent Inequalities. Women and World Development, New York, Oxford University Press.

Milardo, R. (2000): The decade in review, Journal of Marriage and the Family, vol. 62, No. 4, Minneapolis, Minnesota, National Council on Family Relations, November. 
Ocampo, J.A. (2001): Panorama social preocupante, El Mercurio, Santiago, Chile, 27 September.

Olavarría, J. and R. Parrini (eds.) (2000): Masculinidad/es: identidad, sexualidad y familia. Primer encuentro de estudios de masculinidad, Santiago, Chile, Latin American Faculty of Social Sciences (FLACSO)/University of the Academy of Christian Humanism.

Salles, V. and R. Tuirán (1996): Mitos y creencias sobre vida familiar, Revista mexicana de sociología, vol. LVIII, No. 2, Mexico City, Institute of Social Research, National Autonomous University of Mexico, April-June.

(1997): The family in Latin America: A gender approach, Current Sociology, vol. 45, No. 1, London, Sage Publications, January.

Sen, A. (1990): Gender and cooperative conflicts, in I. Tinker, Persistent Inequalities. Women and World Development, New York, Oxford University Press.

(1991): Faltan más de 100 millones de mujeres, La mujer ausente. Derechos humanos en el mundo, "Ediciones de las Mujeres" series, No. 15, Santiago, Chile, IsIs International.

SERNAM (Servicio Nacional de la Mujer) (2001): Mujeres chilenas. Estadísticas para un nuevo siglo, Santiago, Chile.

Théry, I. (1998): Couple, filiation et parenté aujourd'hui. Le droit face aux mutations de la famille et de la vie privée, Paris, Editions Odile Jacob, April.
UNDP (United Nations Development Programme) (1998): Desarrollo humano en Chile. Las paradojas de la modernización, Santiago, Chile.

(2002): Desarrollo humano en Chile. Nosotros los chilenos: un desafio cultural. Informe de Desarrollo Humano en Chile en 2002, Santiago, Chile, May.

Valdés, T. and I. Palacios (1999): Participación y liderazgo en América Latina y el Caribe: indicadores de género, Santiago, Chile, Economic Commission for Latin America and the Caribbean (ECLAC).

Van de Kaa, D.J. (2001): Postmodern fertility preferences: From changing value orientation to new behavior, R. Bulatao and J. Casterline (eds.), Global Fertility Transition, Population Council, New York.

Viveros, M. (1997): Entre familia y trabajo. Las trayectorias sociales de las parejas de doble carrera (un estudio de caso colombiano), paper presented at the IV Conferencia Iberoamericana sobre Familia, Cartagena de Indias, Colombia, 8-12 September.

Wagner, P. (1997): Sociología de la modernidad. Libertad y disciplina, Barcelona, Editorial Herder.

Wainerman, C. (2000): División del trabajo en familias de dos proveedores. Relato desde ambos géneros y dos generaciones, Estudios demográficos y urbanos, vol. 15, No. 1, Mexico City, El Colegio de México, January-April. 